\title{
Empiricism, Constructivism, and Grand Theory in Sociological Approaches to Law: The Case of Transnational Private Regulation
}

\author{
Ioannis Kampourakis ${ }^{*}$
}

(Received 07 September 2020; accepted 13 September 2020)

\begin{abstract}
Sociological approaches to law in both Germany and the UK have been characterized by internal divisions and divergent methodologies and aspirations. While, in the UK, empirical socio-legal studies have been a prominent way of studying how law shapes and is shaped by social institutions, in Germany, the "grand theory" of system-theoretical approaches to law has had a lasting impact. In this Article, I discuss the epistemological contrast between these two sociological approaches to law by focusing on how they address transnational private regulation. Empirical socio-legal studies share an epistemic commitment to an objective and knowable social reality, and they tend to see human actors as the motors of history. Thus they focus on the inter-relational dynamics within Global Value Chains (GVCs), searching for "what works" in transnational private regulation. On the contrary, systems-theory oriented sociological jurisprudence views social reality as constructed and fragmented into the epistemes of different social systems. GVCs are understood as self-referential normative orders, in which the question of agency and human actors is secondary-the emphasis is on communications and anonymous forces of ordering. Attempting to inspect the possibilities for synthesis, I ask how "big" we can and should think in law and society. I thus attempt to outline an approach that starts from the materiality of social structures to investigate processes beyond individual agency and to uncover elements of normative reconstruction of the particular area of social activity.
\end{abstract}

Keywords: Empirical socio-legal studies; constructivism; systems theory; private regulation; transnational law

\section{A. Introduction}

The workshop that inspired this Article set out to trace the convergences and divergences between socio-legal studies in Germany and the UK. My contribution relates to internal debates on the nature and purpose of socio-legal studies broadly understood-or, differently-of "sociological approaches to law." "Such debates have taken place with different intensity and different

\footnotetext{
*Ioannis Kampourakis is a Postdoctoral Researcher at Erasmus School of Law, Erasmus University Rotterdam. Dr. Kampourakis has been a Postdoctoral Fellow at the Edmond J Safra for Ethics at Tel Aviv University and a Postdoctoral Fellow and Associate at the Centre for Socio-Legal Studies at the University of Oxford. Dr. Kampourakis received his $\mathrm{PhD}$ in Law (summa cum laude) from Freie Universität Berlin. He has held visiting appointments at Tel Aviv University, the Riga Graduate School of Law, the Hebrew University of Jerusalem, and the South African Institute of Advanced Constitutional, Public, Human Rights and International Law (SAIFAC).

${ }^{1}$ For the purposes of this contribution, I follow the functional definition provided by Hendry et al., in Socio-Legal Studies in Germany and the UK: Theory and Methods in this issue, according to which socio-legal studies are best defined as "oppositional" to doctrinal legal approaches. In that sense, socio-legal studies become synonymous with-the elsewhere broader — "sociological approaches to law."
}

(C) The Author(s), 2020. Published by Cambridge University Press on behalf of the German Law Journal. This is an Open Access article, distributed under the terms of the Creative Commons Attribution licence (http://creativecommons.org/licenses/by/4.0/), which permits unrestricted re-use, distribution, and reproduction in any medium, provided the original work is properly cited. 
protagonists in both countries. ${ }^{2}$ Indeed, in both Germany and the UK, approaches that claim to study law in light of how it intervenes in social reality have diverged over their prioritized methodologies - that of "empirical research" or that of "grand theory." As empirical research, I understand the research that collects data for the investigation of a particular problem. ${ }^{3}$ Empirical socio-legal research then uses such data to study "the intersections of law and society and the ways in which law and society are co-constitutive and co-existent."4 As grand theory, I understand the attempt to construct a systematic and encompassing theory of the studied relationship or phenomenon, in this case, how law and society interact and shape each other. For the purposes of this Article, I consider both directions to make part of the socio-legal field, broadly understood. A third direction that shares an affinity with the field of "law and society" but which I will not discuss here is that of critical legal studies and theory. ${ }^{5}$

As I will show, the difference between empirical socio-legal research and grand theory-oriented sociological jurisprudence is primarily a difference of epistemology, reflecting the divide between empiricist and positivist aspirations in social sciences on the one hand, and postmodern constructivism on the other hand. In Germany, system-theoretical approaches to law have been an influential current of sociological jurisprudence. I will, therefore, discuss the attempt of legal autopoiesis and of its progeny, societal constitutionalism, to present a unifying theory of law and society without relying on the provision of raw data from field research. ${ }^{6}$ Societal constitutionalism builds on the epistemological and analytical premises of systems theory and legal autopoiesis. However, contrary to the latter, it also suggests a normative framework as an answer to the question of how to constrain the expansionary and potentially destructive dynamics of social systems. The reliance on the same constructivist assumptions as systems theory and the engagement with normative thinking makes societal constitutionalism a particularly strong representation of grand theory in contemporary sociological jurisprudence and, thus, a good instance for the comparative work I want to undertake. In the UK, empirical socio-legal research has arguably been a more prominent way to study the law and society nexus. In line with the comparative aspirations of this Special Issue, I will then discuss the underlying methodological and epistemological assumptions of empirical approaches to law. I will draw the comparison between these two different sociological approaches to law by focusing on how they address one increasingly important aspect of legal and social ordering under conditions of globalization, that of transnational private regulation. Unavoidably, the conclusions I draw from this comparative endeavor cannot do absolute justice to the richness of nuances that exist within the paradigms of empirical socio-legal studies or system-theoretical approaches to law. Yet, the discussion of their underlying epistemologies and how these epistemologies inevitably

\footnotetext{
${ }^{2}$ See Stefan Machura, Milestones and Directions: Socio-Legal Studies in Germany and the United Kingdom, in this issue; Alfons Bora, Sociology of Law in Germany: Reflection and Practice, 43 J.L. \& Soc'y 619 (2016); Max Travers, Sociology of Law in Britain, AM. Sociologist 26 (2001).

${ }^{3}$ Lee Epstein \& Andrew D. Martin, An Introduction to Empirical Legal Research 3-4 (2014).

${ }^{4}$ Margaret Davies, Doing Critical Socio-Legal Studies 88 (Naomi Creutzfeldt et al. eds., 2020).

${ }^{5}$ Critical legal approaches occasionally share the sociological, non-doctrinal viewpoint of socio-legal studies. Without the holistic aspirations of "grand theory," critical legal studies approach the law-society nexus through an abstract inquiry into the significance of legal structures or through a critical rationalization and explication of doctrinal choices. See CosTAS DouzINAS \& Adam Gearey, Critical jurisprudence: The Political Philosophy of Justice (2005). For the critique that recent critical legal theory has tended to be ethical, rather than socio-historical in its form, see Alan Norrie, From Critical to Socio-Legal Studies: Three Dialectics in Search of a Subject, 9 Soc. \& LEGAL STUD. 85 (2000). "Law and Economics" also shares the external perspective to the study of the law. See Richard A. Posner, Frontiers of Legal Theory 3 (2001). However, Law and Economics' distinct ambitions and historical development justify not considering it part of the "law and society" movement. As such, I do not discuss it here. See also John J. Donohue, III, Law and Economics: The Road Not Taken, 22 L. \& Soc. Rev. 903 (1988).

${ }^{6}$ For an introduction to systems theory, see Niklas Luhmann, Introduction to Systems Theory (2012) [hereinafter Luhmann, Introduction to Systems]. For legal autopoiesis, see Niklas Luhmann, LaW as a Social System (2004) [hereinafter LUHMANN, LAw]. For societal constitutionalism, see generally GunTHER Teubner, Constitutional Fragments: Societal Constitutionalism and Globalization (2012).
} 
structure distinct projects captures an essential aspect of the debates about the nature and purpose of sociological approaches to law. It also provides an insight into the divergent development of law and society in the UK and Germany.

The case study that I use to uncover the different starting points, aspirations, and results of empirical socio-legal research and system-theoretical analysis is that of transnational private regulation. Private regulation I understand as the "voluntary, private, non-state industry and cross-industry codes that address labor practices, environmental performance, and human rights policies." a form of legal pluralism, private regulation poses a challenge to legal centralism and state sovereignty, making doctrinal approaches to law ill-suited to capture its significance. Considering that private regulation does not depend on the coercive power of the state apparatus and, in that sense, is not a product of a national legal order, it could be readily dismissed as a non-legal phenomenon. ${ }^{8}$ Yet, private regulation produces binding and otherwise normative effects on the ground for a plurality of actors in global supply chains. The non-doctrinal, "beyond the books" perspective of sociological approaches to law is sensitive to this normativity that is not linked to state law.

Empirical socio-legal studies approach transnational private regulation through the specificities of each particular context: Which actors are involved; how it is applied in practice; whether it has an impact, and, if so, what the reasons behind its success are. Although a general conclusion about all empirical socio-legal work in the field of transnational private regulation is beyond the aspirations of this Article, the four research works that I analyze point to the conclusion that an emphasis on "context" and, eventually, a level of particularism, is a shared and unifying theme of this strand of research. Underlying this type of sociological approach is an epistemic commitment to an objective and knowable social reality and, to a certain extent, a methodological individualism, ${ }^{9}$ which seeks to explain social phenomena in terms of facts about individuals.

In line with systems theory, societal constitutionalism approaches transnational private regulation the opposite way: Fitting concrete instances into its bigger theoretical framework. Systems theory posits that society is fragmented into multiple systems of communication that do not interact directly with one another. Instead, each system translates "irritations" 10 from its environment into its own code communication. As a result, change cannot be imposed upon systems but rather stems from "within" each social system. ${ }^{11}$ Societal constitutionalism adds a normative dimension to this descriptive framework by suggesting that social systems need to develop forms of self-limitation and internal democratization. ${ }^{12}$ This "constitutionalization" of social systems is necessary in a world where dangers for the social fabric do not emanate solely from political power but

\footnotetext{
${ }^{7}$ David Vogel, The Private Regulation of Global Corporate Conduct, 49 Bus.\& Soc'y 68, 68 (2010).

${ }^{8}$ On the debate on voluntary/binding character of instances of transnational private regulation, see Florence Palpacuer, Voluntary Versus Binding Forms of Regulation in Global Production Networks: Exploring the "Paradoxes of Partnership," in The European Anti-Sweatshop Movement (Geert de Neve \& Rebecca Prentice eds., 2017); Radu Mares, Global Corporate Social Responsibility, Human Rights and Law: An Interactive Regulatory Perspective on the Voluntary-Mandatory Dichotomy, 1 Transnat. Legal Theory 221 (2010); John Gerard Ruggie, Multinationals as Global Institution: Power, Authority and Relative Autonomy, 12 Reg. \& Governance 317 (2018). According to Gunther Teubner, Global Bukowina: Legal Pluralism in the World-Society, in Global LAW WithouT A STATE 7 (Gunther Teubner ed., 1996):
}

$[\mathrm{O}] \mathrm{n}$ this [legal centralist, doctrinal] viewpoint, any legal phenomenon in the world necessarily has to be "rooted" in a national legal order; it needs at least a "minimal link" to national law. Lex mercatoria will never develop into an authentic legal order because it does not regulate an exclusive territory with coercive power.

\footnotetext{
${ }^{9}$ On the historical waves of methodological individualism, see Joseph HEATH, METHODOLOGICAL INDIVIDUALISM (Edward N. Zalta ed., 2020). For a defense, see Steven Lukes, Methodological Individualism Reconsidered, 19 THE BRITISH J. SOC. 119 (1968). For a critique, see Roy Bhaskar, On the Possibility of Social Scientific Knowledge and the Limits of Naturalism, 8 J. Theory Soc. Behav. 1 (1978).

${ }^{10}$ Luhmann, LaW supra note 6, at 258-259.

${ }^{11}$ Gunther Teubner, InTroduction to Autopoietic Law 7-8 (Gunther Teubner ed., 1987).

${ }^{12}$ Teubner, supra note 6, at 83-86, 88-89. See also Gunther Teubner, Substantive and Reflexive Elements in Modern Law, 17 L. \& Soc'y REV. 239, 266-270. (1983).
} 
also from other systems, most prominently the economy. ${ }^{13}$ Transnational private regulation appears as a fitting instantiation of this theoretical framework, as it represents attempts of economic actors to self-limit, often in response to social pressures - to irritations from their environment. Underlying this approach to understanding private regulation is, first, a constructivist epistemology that views social reality as constructed and fragmented into the epistemes of different social systems. Second is an anti-individualism that refuses to see human actors as the agents of social action and points instead to constructs, the communications of which human actors express in their social interactions. ${ }^{14}$

While these approaches initially appear irreconcilable and each has its own value as a distinct project, I believe that there is also a margin for a middle ground, or, more ambitiously, for synthesis. This emerges when considering whether there is a spectrum between an encompassing theory of society and sectoral approaches into the specificities of particular social problems. In other words, what are the degradations of thinking "big" in law and society? In that direction, this Article attempts to draw the contours of an approach that focuses on the materiality of social structures. This materiality can be empirically examined not only to provide context-specific insights, but also to uncover elements of normative reconstruction of the particular area of social activity. If frameworks that present themselves as merely "descriptive" do in fact convey implicit normative presuppositions, then empirical research has an inherent potential for normative thinking that extends beyond institutional reforms. A synergetic approach would start inductively from the empirical examination of the materiality of social structures to investigate and possibly to challenge processes that take place beyond individual agency.

In Section B, I show how empirical socio-legal studies and also legal autopoiesis and societal constitutionalism share an external — as opposed to internal, in other words, doctrinal-perspective to law, but differ in their epistemological bases. In Section C, I discuss in detail the response of sociolegal studies and societal constitutionalism to the conundrum of transnational private regulation. In particular, I focus on the role each approach attributes to agents and structures in Global Value Chains (GVCs). In Section D, I attempt to outline a role for "thinking big" in sociological approaches to law and to trace elements of possible convergence between the different approaches. I conclude the Article with a brief summary of the main points discussed and with a note on how thinking on synergies might develop further.

\section{B. Empirical Socio-Legal Studies and Legal Autopoiesis: Converging Perspectives, Diverging Epistemologies}

Legal autopoiesis, the conceptual foundation of societal constitutionalism, and empirical socio-legal studies both follow the "sociology of law" tradition of thinking about the law from an "external," observer's perspective. ${ }^{15}$ Where "restricted legal theory" 16 adopts a standpoint that is internal to state-based law, aspiring to work out how law is or is meant to be interpreted by legal practitioners, sociological theories of law deliberately distance themselves from the professional viewpoint of the legal practitioner. The limitations of the internal perspective are captured by David Schiff, according to whom "jurisprudence writers in general, have tended to show a lack of concern for an analysis of the structure of society which accounts for the workings of the legal

\footnotetext{
${ }^{13}$ Science and technology or the media-including social media-are further social systems, the unfettered expansion of which might be detrimental to the social fabric. See Teubner, supra note 6, at 1.

${ }^{14}$ For this core notion of systems theory, see Niklas Luhmann, Theory of Society 6-13. (2012).

${ }^{15}$ Roger Cotterrell, The Sociological Concept of Law, 10 J.L. \& Soc'y 241, 242-43 (1983).

${ }^{16}$ According to Douzinas \& GEAREY, supra note 5, at 10-11, by focusing on the question "what is law ", "restricted legal theory" is bound to seek the characteristics that define the "essence" of the law, limiting the legal phenomenon to particular institutions, practices, and actors.
} 
systems." ${ }^{17}$ To address this shortcoming, sociological theories have attempted to answer broader questions about the role of law in society, its relation to political and economic structures, or its role in historical change and social transformation. ${ }^{18}$ In that direction, legal autopoiesis is not interested in questions of jurisprudence for their interpretative value for doctrine or case law. Rather, it uses them to distill a broader principle of social theory-the self-referentiality of the law. This becomes instrumental in conceptualizing law as a social system wherein the "paradox" of self-referentiality is not something to be resolved but is rather constitutive of the system and structural in making it operational. ${ }^{19}$ Similarly, empirical socio-legal studies are not employing empirical designs to evaluate the internal coherence of the legal doctrine. Instead, they seek to test assumptions about the operations of the legal system and to study how the law affects or is affected by various social institutions. ${ }^{20}$

Starting from such an external perspective and a sociological concept of law, empirical legal research, for many a core element of socio-legal studies, attempts to use the methods of social sciences and study law and legal practices in an objective light, as a set of observable facts. According to Simon Deakin, this type of approach is based on the premise that data gathered through empirical research is "capable of representing features of the social world which exist independently of the process of inquiry which is being used to study them." ${ }^{21}$ In other words, empirical legal research is underpinned by the idea that, within a particular social context, there can be objective knowledge that is not merely interpretative or hermeneutics. ${ }^{22}$ Such "truth" can be attained, or at least approached, through the rules of good scientific practice. Admitting the possibility of objective empirical knowledge, even with a role for intellectual construction, follows the currents of logical empiricism and positivism in social sciences. ${ }^{23}$ Historically, the aspiration behind the use of empirical methods has been to transform society through the use of knowledge: Even in the absence of concrete predictions, the data gathered by social sciences provides a framework of argumentation, dispelling speculative metaphysical doctrines. ${ }^{24}$

\footnotetext{
${ }^{17}$ David N. Schiff, Socio-Legal Theory: Social Structure and Law, 39 MoD. L. ReV. 287, 289 (1976).

${ }^{18}$ Davies, supra note 4 , at 88 .

${ }^{19}$ Gunther Teubner, How the Law Thinks: Toward a Constructivist Epistemology of Law, 23 L. \& Soc'y REV. 727, 736 (1989).

${ }^{20}$ See David M. Trubek, Where the Action Is: Critical Legal Studies and Empiricism, 36 STAN. L. REV. 575, 581 (1984) ("[L]aw cannot be defined other than by the difference it makes in society, and empirical inquiry is necessary to determine what that is."); Carrie Menkel-Meadow, Uses and Abuses of Socio-Legal Studies, in Routledge Handbook ON SociO-LEGAL TheORY AND Methods 43 (Naomi Creutzfeldt et al. eds., 2020):
}

[W] here legal scholars have focused on doctrinal developments and often argue for law reform, often without any reference to empirical data ... socio-legal scholars have been especially good at focusing on non-uniform impacts of law (various forms of patterning by race, class, gender, and other characteristics), the contextual conditions that may be necessary for legal policies to be effective.

\footnotetext{
${ }^{21}$ Simon Deakin, The Use of Quantitative Methods in Labour Law Research, 27 Soc. \& LEGAL STUD. 456, 458 (2018).

${ }^{22}$ Geoffrey Samuel, Does One Need an Understanding of Methodology in Law Before One Can Understand Methodology in Comparative Law?, in Methodologies OF Legal ReSEARCH 189 (Mark van Hoecke ed., 2011).

${ }^{23}$ See Filipe J. Souza, Meta-Theories in Research: Positivism, Postmodernism, and Critical Realism, in 16 ORGANIZATIONAL Culture, Business-To-Business Relationships, ANd InTERfirm Networks (AdVANCes in Business Marketing AND Purchasing (Arch G. Woodside ed., 2010) (describing the explicit case for the "Empirical Legal Studies" movement in the U.S., and citing Elizabeth Chambliss, When Do Facts Persuade - Some Thoughts on the Market for Empirical Legal Studies, 71 L. \& Contemp. Probs. 17, 32 (2008)).

${ }^{24}$ See Otto Neurath et Al. eds., InTernational Encyclopedia of Unified Science 46 (1944). The role of scientific progress and expertise was also an important aspect of legal realism, see Oliver Wendell Holmes, The Path of the Law, 110 HARV. L. REV. 991, 1001 (1997 [1897]), according to whom "the man of the future is the man of statistics and the master of economics. " Legal realism has been invested in highlighting the distance between "law in the books" and "law in action," an effort that can only be achieved through empirical study of social facts pertaining to legal endeavors; see also Hanoch Dagan, The Realist Conception of Law, 57 U. TorONTO L.J. 607 (2007). For a reappreciation of positivism's progressive and even socialist angle before its fall into dismay amongst critical thinkers, see John O'Neill, In Partial Praise of a Positivist: The Work of Otto Neurath, 074 RadiCAL PHIL. (1995). Similarly, yet denouncing the label of "positivism," Trubek, supra note
} 
On the contrary, legal autopoiesis, and by extension, societal constitutionalism, relies on a postmodern, constructivist social epistemology, according to which there is no "reality" to be discovered. Instead, "reality" is constructed. In the case of law, it is law itself as an epistemic subject that constructs its own reality. ${ }^{25}$ Systems theory posits that society is differentiated into distinct social systems, each with its own code of communication and, inevitably, its own episteme. In fact, the loss of a "unifying mode of cognition" 26 is a fundamental attribute of modern society. As each social system constructs its own reality, law becomes a "self-validating discourse ... largely impervious to serious challenge from other knowledge fields." 27 This perspective leads to a foundational clash with the positivist ontological underpinnings of empirical socio-legal studies and their invocation of the authority of controlled scientific observation as a privileged access to reality. As Gunther Teubner emphasizes, following Niklas Luhmann, "science does not discover any outside facts; it produces facts." 28 Similarly, law is self-referential and produces its own distinctions and categories. Most characteristically, law should not be understood as a product of particular individuals' actions_-including, legislators and judges. Instead, it is law itself as a communicative process that "produces" human actors as its semantic artifacts. ${ }^{29}$

The epistemological divide between socio-legal studies and societal constitutionalism corresponds to the epistemological and ontological divide between positivism, empiricism, and rationalism on the one hand, and constructivism on the other hand. ${ }^{30}$ As I will show in the following section, the empirical dimension and largely positivist ontology of empirical socio-legal studies result in a study of the inter-relational dynamics of the actors within GVCs, constituting an effort to uncover "what works" in transnational labor law. On the contrary, societal constitutionalism starts from an understanding of GVCs as self-referential normative orders in which the question of agency and particular actors is secondary. Instead, the normative dimension of societal constitutionalism places the emphasis on the structures and mechanisms that may generate self-regulatory dynamics within social systems, such as human rights or the corporate codes of lead firms. ${ }^{31}$

\section{Case Study: Agency and Structure in Global Value Chains}

The fact that multiple systems of ordering, not necessarily linked to the legitimate state legal order, might co-exist in the same place at any one time has since long been recognized and theorized by

20 , at 580, according to whom those that use empirical methods in legal scholarship are driven by practical concerns, as opposed to an epistemological commitment to positivism or a belief in determinism-this is a commitment to "pragmatism." At the same time, empiricism has also roots in Karl Popper's "rationalism" and the idea that beliefs are rationally grounded only if they can pass a "crucial experiment test" — an approach that led to the dismissal of Utopian social philosophy. See KARL R. Popper, The Open Society And Its Enemies (2013).

${ }^{25}$ Teubner, supra note 19 at 730 .

${ }^{26} I d$. at 738.

${ }^{27}$ Roger B.M. Cotterrell, Law and Sociology: Notes on the Constitution and Confrontations of Disciplines, 13 J.L. \& Soc'y 9 , 15 (1986)

${ }^{28}$ See Teubner, supra note 19, at 743 (attacking "law and society" approaches-meaning, here, empirical socio-legal approaches - as "the celebrated controlled experiment is not what it pretends to be, a test of an internal theory against external reality, but is a mere internal coherence test comparing two constructs that are produced according to different procedural requirements: The logic of theoretical reasoning and the logic of the laboratory"). According to NIKLAS LUHMANN, WISSENSCHAFT 2, 9 (1988), "science produces a construction of the world which is validated by its distinctions and not by the world as such. Thus, science cannot claim the authority to discover the only and the correct access to the real world and to communicate this to others." According to LUHMANN, supra note 14, at 16, "the coincidence of empirical knowledge and reality cannot be empirically determined, and from an epistemological point of view must accordingly be treated as accidental."

${ }^{29}$ Teubner, supra note 19 , at 741 .

${ }^{30}$ For a brief impression of this recurrent debate, see how Max Horkheimer of the Frankfurt School, in his 1937 article The Latest Attack on Metaphysics, attacks Vienna Circle's neo-positivism for political quietism and for furnishing unwitting assistance to fascism, Max Horkheimer, Critical Theory: Selected Essays (1972).

${ }^{31}$ See generally TeUBNER, supra note 6 . 
socio-legal research. ${ }^{32}$ Private regulation is one instance of this type of legal pluralism. The different ways it has been probed and studied within the socio-legal field flesh out how the different epistemological and methodological assumptions of empirical socio-legal studies and grandtheory sociological jurisprudence lead to divergent ways of conceptualizing the phenomenon and to distinct normative projects.

In a global economy characterized by an organizational system of vertical disintegration, fragmented ownership, and dispersed production, lead firms have managed to keep manufacturing-related concerns outside the legal boundaries of the firm. ${ }^{33}$ However, as an appeal to consumers or as a result of social pressures often following a moment of crisis, ${ }^{34}$ lead firms have, in many cases, instituted private regulatory regimes that aspire to improve working conditions within supply chains. Currently, the labor aspect of transnational private regulation and the question of lead firm accountability for human rights violations in global supply chains is becoming a growing concern in both studied countries. In Germany, the Jabir $v$ KIK case of 2019 highlighted that it might be possible to establish lead firm liability based on obligations assumed by the firm and incorporated in corporate codes that make part of supply chain agreements. ${ }^{35}$ Similarly, in the UK, the 2019 Lungowe and Ors. $v$ Vedanta Resources Plc and Konkola Copper Mines $P l c$ case underscored that a UK parent company could arguably owe a duty of care to the people affected by its subsidiary's operations. ${ }^{36}$

Yet, the normativity and the social reality of transnational private regulation pose a challenge to traditional conceptions of law that have as their starting point legal centralism and state sovereignty. ${ }^{37}$ This makes the external perspective of sociological approaches to law uniquely suited to examine this phenomenon. Empirical socio-legal studies are often concerned with "what works" in transnational private regulation - in other words, what can be evidenced as having an effect. Drawing from the positivist ontology of social sciences and from a methodological individualism that unpacks collective phenomena through the agency of individual actors operating in particular contexts, empirical work concentrates on context, specific case studies, and actors in the value chain. The caveats of inductive reasoning notwithstanding, the researched case studies help to draw lessons of broader theoretical significance. For the purposes of this Article, I summarize four such attempts to delve into the specificities of GVCs, to trace the impact of corporate codes of conduct, and to discern how they interact with public regulation, or what meaning they may acquire when used by local actors as leverage. In these cases, the authors generally refrain from postulating a grand theoretical framework. Any attempts to understand the structure of GVCs and the role of private regulation therein are deduced from the data acquired through the research, the subjects of which are specific actors within the value chain-for example, workers and unions.

\footnotetext{
${ }^{32}$ See Sally Engle Merry, Legal Pluralism, 22 L. \& Soc'y REv. 869 (1988).

${ }^{33}$ Gary Gereffi et al., The Governance of Global Value Chains, 12 REv. INT'L POL. ECON. 78 (2005).

${ }^{34}$ For example, the hybrid regulatory regime of the Bangladesh Accord on Fire and Building Safety in Bangladesh was established following the collapse of the Rana Plaza in 2013 and the death of 1,134 people, most of them garment workers.

${ }^{35}$ See Landgericht Dortmund [LG] [Dortmund Regional Court], 7 O 95/15 (filed Mar. 13, 2015) (Ger.) (eventually rejected on the basis that the statute of limitations had expired).

${ }^{36}$ See Lungowe and Ors. v. Vedanta Resources Plc and Konkola Copper Mines Plc [2017] [EWCA] (Civ) 1528 (holding that a UK parent company could arguably owe a duty of care to the people affected by its subsidiaries' operations, on the grounds of the "high level of control and direction" that the parent company exercised over the subsidiary); Even though this case concerns individuals affected by the operations of a subsidiary who are not employees of the subsidiary, it eventually follows Chandler v. Cape Plc [2012] [EWCA] (Civ) 525, where the parent company was found to have assumed a duty of care towards the employees of its subsidiary, who had been exposed to asbestos. This was a result of the parent company's "state of knowledge" about the factory in which these employees worked and "its superior knowledge about the nature and management of asbestos risks" in relation to the operations of the subsidiary [78].

${ }^{37}$ Teubner, supra note 8 , at 6-7.
} 


\section{Empirical Studies}

One example in this direction is the work of Tim Bartley and Niklas Egels-Zanden, who employ qualitative research methods to interrogate the common hypothesis of the "decoupling" between the symbolic CSR commitments of lead firms and concrete work practices. ${ }^{38}$ In particular, they are interested in how local actors within the value chain use the leverage provided by CSR codes to achieve improvements in working conditions. NGOs and especially trade unions use these largely symbolic structures as resources and an opportunity to enroll other actors in order to achieve local goals. ${ }^{39}$ One prominent example of such CSR leveraging is "brand boomerang" campaigns, in which union activists facing repression from factory managers cooperate with international allies to pressure lead buyer firms. ${ }^{40}$ Yet, the authors point out further avenues taken by Indonesian unions in using CSR commitments to advance their causes. Unions appeal to brands' compliance staff to resolve grievances with factory managers or use the possibility to do so as a form of pressure during negotiations. They also occasionally attempt to engage in capacity-building and participate in standard-setting together with lead firms. In all these instances, the addressee of the demand to promote workers' rights is the lead firm of the value chain, as opposed to the government. ${ }^{41}$ Considering the occasional and limited success of such strategies, Bartley and Egels-Zanden suggest that, instead of complete decoupling, it is more suitable to think of CSR and actual labor practices in terms of "contingent coupling." The coupling is contingent because it emerges out of highly contextual contention beyond universalizable recipes for success, and it only temporarily addresses structural, underlying problems, with transformative gains being rare. ${ }^{42}$

Another example of empirical research in transnational private regulation that highlights the importance of context is that of Greg Distelhorst and others in the electronics industry. ${ }^{43}$ Using quantitative analysis of factory audits and qualitative fieldwork to identify the institutional

\footnotetext{
${ }^{38}$ Tim Bartley \& Niklas Egels-Zandén, Beyond Decoupling: Unions and the Leveraging of Corporate Social Responsibility in Indonesia, 14 Socio-Econ. Rev. 231, 233 (2016). For the hypothesis of decoupling, see John W. Meyer \& Brian Rowan, Institutionalized Organizations: Formal Structure as Myth and Ceremony, 83 AM. J. Soc. 340 (1977); Luc Fransen, MultiStakeholder Governance and Voluntary Programme Interactions: Legitimation Politics in the Institutional Design of Corporate Social Responsibility, 10 SocIO-ECON. REV. 163 (2012); Dima Jamali, MNCs and International Accountability Standards Through an Institutional Lens: Evidence of Symbolic Conformity or Decoupling, 95 J. Bus. ETHICS 617 (2010).

${ }^{39}$ See the notion of "principled opportunism" in Marxist theory, Robert Knox, Marxism, International Law, and Political Strategy, 22 Leiden J. INT'L L. 413, 433 (2009). See also Evan Schofer \& Ann Hironaka, The Effects of World Society on Environmental Protection Outcomes, 84 SOC. FORCES 25 (2005) (demonstrating how this dynamic is also examined in world society theory).

${ }^{40}$ In a well-known case, independent unions at the Kukdong factory in Mexico and BJ\&B factory in the Dominican Republic successfully gained collective bargaining rights after international campaigns pressured Nike to support freedom of association, Bartley \& Egels-Zandén, supra note 38, at 236. See also César A. Rodríguez-Garavito, Nike's Law: The AntiSweatshop Movement, Transnational Corporations, and the Struggle over International Labor Rights in THE AMERICAS (Boaventura de Sousa Santos \& César A. Rodríguez-Garavito eds., 2009).

${ }^{41}$ On how this strategy increases "the very power of corporations that the campaigns aimed to denounce and circumscribe, vesting lead firms with a new form of political authority based on private regulation schemes in global production networks," see Palpacuer, supra note 8 , at 80 .

${ }^{42}$ Empirical research has already shown that corporate codes can lead to improvements in outcome standards, while they change little in process rights for workers and cannot comprehensively challenge existing commercial practices of exploitation, see Stephanie Barrientos \& Sally Smith, Do Workers Benefit From Ethical Trade? Assessing Codes of Labour Practice in Global Production Systems, 28 THIRD WORLD Q. 713 (2007). See also Richard M. Locke et al., Does Monitoring Improve Labor Standards? Lessons from Nike, 61 INDUs. \& LAB. REL. REV. 3 (2007) (reviewing factory audits of working conditions in over 800 of Nike's suppliers and found that monitoring had only limited results); DARA O'ROURKE, MONITORING THE MONITORS: A Critique of PricewaterhouseCoopers' Labor Monitoring (2000) (employing ethnographic research, which included observing monitors at work, to reveal the weaknesses of the monitoring system).

${ }^{43}$ Greg Distelhorst et al., Production Goes Global, Compliance Stays Local: Private Regulation in the Global Electronics Industry, 9 REG. \& Gov. 224.
} 
dimensions that complement private regulation, the authors suggest that the local institutional context is the most significant predictor of private regulation being effective at improving labor standards. Strong state regulatory institutions and a strong local civil society are crucial for meaningful compliance, while they also enable synergies with private regulation that lead to higher standards of labor rights protection. ${ }^{44}$ Specifically, the authors examined how Hewlett-Packard (HP) monitors and facilitates the compliance of its suppliers with the voluntary Electronics Industry Citizenship Coalition (EICC) code that HP helped establish in 2004. While factory audits reveal that suppliers are far from fully compliant, ${ }^{45}$ working conditions appear to have improved as a result of HP's engagement with suppliers. ${ }^{46}$ Yet, the rate of improvement and compliance with social standards is best explained not by factory-level predictors, but rather by examining the local institutional environment. In countries with weaker regulatory institutions, including developing countries, the strength of civil society becomes a differentiating factor for the effectiveness of compliance. For example, in Mexico, the mediation of a local NGO led to the creation of a relatively successful collaborative dispute resolution institution that subsidized inefficient state institutions. By contrast, in China, such civil society partners were not easily available, and unionization did not sufficiently advance worker interests. ${ }^{47}$ As a result, compliance with the EICC was lower and private regulation could not sufficiently complement lax state enforcement of labor laws. Overall, Greg Distelhorst and others underscore that the local institutional context is vital for the success of transnational private regulation, while private and public regulatory regimes should be thought of as complements rather than rivals.

The study conducted by Andrew Crane and others on forced labor in domestic supply chains in the UK offers another example of focusing on the institutional context to untangle the particular workings of GVCs. ${ }^{48}$ Shifting the spotlight from the developing world to forced labor in developed countries, they draw attention to the role of labor market intermediaries. For example, the construction and food industries make significant use of "temporary, casual, and other forms of contingent labor, the supply of which is often outsourced to third-party labor providers." ${ }^{49}$ While a key factor for the emergence of forced labor in GVCs is the price pressure exerted by buyers from the Global North on manufacturers in the developing world, in supply chains of the Global North the division of legal status and protections offered to workers depending on their country of origin is critical. The contrast between domestic and global supply chains becomes even more prominent in the discussion of remedies and solutions to such governance gaps. While GVC scholarship emphasizes the potential of private regulation and explores the possibilities for reconfiguring private law instruments along the value chain, ${ }^{50}$ domestic supply chains bring to the foreground the state, regulatory enforcement, licensing, and policing. In a sense, this is a response to another difference between global and domestic supply chains-their level of complexity. As Crane and others point out, the "cult of complexity" that surrounds global supply chains overlooks important aspects of simplicity within domestic supply chains. ${ }^{51}$

\footnotetext{
${ }^{44}$ On how private compliance efforts are layered upon traditional forms of regulation, see D.M. Trubek \& L.G. Trubek, New Governance and Legal Regulation: Complementarity, Rivalry or Transformation, 13 CoLUM. J. EUR. L. 539 (2007). On the question of designing CSR and governance mechanisms that effectively engage with local variations, see Luc Fransen, The Embeddedness of Responsible Business Practice: Exploring the Interaction Between National-Institutional Environments and Corporate Social Responsibility, 115 J. Bus. ETHICs 213 (2013).

${ }^{45}$ Distelhorst et al., supra note 43, 228 (“42 percent of audited facilities were non-compliant in wages and benefits.”).

${ }^{46} I d$. at 228.

${ }^{47} I d$. at 236 (explaining that low percentages of participation and underfunding are pointed out as reasons for this failure).

${ }^{48}$ Andrew Crane et al., Governance Gaps in Eradicating Forced Labor: From Global to Domestic Supply Chains, 13 REG. \& Gov. 86, 93 (2019).

${ }^{49} I d$. at 93.

${ }^{50}$ See The IGLP Law and Global Production Working Group, The Role of Law in Global Value Chains: A Research Manifesto, 4 LONDON REV. INT'L L. 57 (2016).

${ }^{51}$ Crane et al., supra note 48 , at 101 .
} 
Critical in the suppression of forced labor in domestic supply chains then becomes the coordination of already-existing hierarchy- and market-based initiatives designed to address labor abuses, as well as regulation around immigration and other structural conditions that promote vulnerability to exploitation. ${ }^{52}$ Eventually, this accentuates the importance of politics, as opposed to capacity deficits.

Anthropological and ethnographic work within GVCs reinforces the idea that structures of exploitation are contextual. This also supports the conclusion that the normativity of private regulation needs to be addressed in its particular instantiations. Anna Tsing, in her study of supply chain capitalism, draws attention to the fact that the cultural diversity of GVCs is a structural element of the processes of exploitation that develop within the chain. ${ }^{53}$ In other words, according to Tsing, supply chains vitalize performances of non-economic features of identity and neutralize worker negotiation leverage to maximize exploitation beyond what would be expected from general economic principles-for example, Christian service work at Wal-Mart, women from the Global South with sewing skills learned at home, coding work as entrepreneurship for white men holding on to independence, etc. As diversity becomes ingrained in the processes that make GVCs operational, any comprehensive legal and political theory of supply chain capitalism would have to take into account the "full tapestry" of gender, race, and national status through which exploitation becomes possible. ${ }^{54}$ A theory of transnational labor rights and "decent work" can only aspire to be normative through context, through the lived reality of intersecting structures of exploitation. There can be no unifying theory of emancipation designed on paper; instead, theory-building must start from the ground up.

\section{Societal Constitutionalism}

Does then this emphasis on context and particularity preclude the possibility of a grand theory of supply chain capitalism? Societal constitutionalism shifts the focus from agents to structure, conceptualizing context as an integral feature of its grand theory. The move to structure and the core methodological challenge societal constitutionalism poses to empirical socio-legal approaches does not consist of simply taking into consideration the aggregate dynamics arising from the decentered use of private autonomy. That is something empirical approaches are attentive to, as manifested in the examples above, such as the cumulative and strategic use of codes of conduct in Bartley and Egels-Zanden. Rather, it consists of undermining the fundamental assumption that individuals are the agents of social action and, eventually, the makers of history. The system-theoretical underpinnings of societal constitutionalism draw attention to constructs, primarily to self-organized systems of communication. In system-theoretical terms, humans cannot be thought of as independent agents, beyond the confines of social systems; instead, they partake in multiple and overlapping systems of communication, the codes and functions of which they express through their actions. As a result, the individual is not the basic unit of analysis. She is a medium through which the workings of broader social systems become manifest.

This defines both how to understand society and how to envision social transformation. As society is imagined, divided into multiple self-referential social systems, which remain functional only by translating external complexity to their own code of communication, change and evolution can only happen in one way: System-internally. ${ }^{55}$ Social transformation is only possible

\footnotetext{
${ }^{52} I d$. at 102.

${ }^{53}$ Anna Tsing, Supply Chains and the Human Condition, 21 Rethinking MarXISM 148 (2009). See also Hannah Appel, Race Makes Markets: Subcontracting in the Transnational Oil Industry, Soc. SCI. RES. CounCIL (2018), https://items.ssrc.org/ race-capitalism/race-makes-markets-subcontracting-in-the-transnational-oil-industry/.

${ }^{54}$ Tsing, supra note 53 , at 172 .

${ }^{55}$ Teubner, supra note 11 , at $1,7-8$.
} 
through the internal workings of social systems, as opposed to superimposition by external agents, such as the state. Effective limitations on the destructive expansion of social systems, like the economy, can only be the result of system-specific logic. ${ }^{56}$ In the context of the economy, this is because of two main reasons. The first is that the necessary knowledge for inhibiting a catastrophic expansion of economic rationalities cannot be built from external observation points, such as that of the state. There is no comprehensive, centralized knowledge that can capture, let alone regulate, the hyper-complex processes of the global economy. ${ }^{57} \mathrm{~A}$ mundane manifestation of this lack of epistemic and enforcement capacity is the way transnational corporations manage to circumvent and avoid ex-ante regulations, such as taxation. The second reason is that if politics is left to define the fundamental principles of other social systems, such as that of the economy, there is a risk of de-differentiation of society and of slippage to totalitarianism in which politics aspires to represent the whole of society. ${ }^{58}$

Therefore, the solutions to the conundrums of decent work, sustainable development, and even social justice and equality, lie within the transnational economy itself. GVCs must be understood as normative orders in need of constitutionalization..$^{59}$ However, the constitutionalization process must not replicate that of the political system. ${ }^{60}$ Different, non-state, social structures develop their own forms of self-limitation that amount to constitutionalization through their autonomous processes. This often happens ad hoc at the emergence of a particular social problem. ${ }^{61}$ There is no single, all-encompassing social constitution - only "islands of the constitutional in the sea of globality." 62

One way of envisioning such transnational constitutionalization of the economy is through corporate codes of conduct. ${ }^{63}$ By applying to contractors and subcontractors, the codes of transnational corporations constitute regimes of corporate self-governance that coordinate and homogenize outsourced production. While originally designed for guaranteeing product and service standards, such codes have the potential to - and often, indeed, do-expand into areas traditionally understood as "externalities" of the supply chain: The safeguarding of labor rights among suppliers or the impact of the outsourced production on the environment. ${ }^{64}$ The genesis of these codes may be traced to the susceptibility of lead firms to "learning pressures," that is, to external pressures, such as reputational sanctions, that lead to internal self-limitation. Such pressures may result from court cases of supply chain liability, soft international legal norms, or civil society pressures and political consumerism. Contrary to state-initiated soft law on the social

\footnotetext{
${ }^{56}$ Gunther Teubner, A Constitutional Moment? The Logics of 'Hitting the Bottom,' in The FINANCIAL CRISIS IN Constitutional Perspective 5 (Poul F. Kjaer et al. eds., 2011). As mentioned above, supra note 14, the same logic applies with regards to the expansion of other social systems. For example, with regards to the legal system, human rights serve as a counterinstitution wherein the self-limitations to the expansion of the system are congealed.

${ }^{57}$ On the convergence between systems theory and the Hayekian insistence on "constitutional ignorance" and the "unknowability" of the global economy, see Quinn SLObOdian, Globalists: The END OF EMPIRE AND THE BirTh OF NEOLIBERAlism, 224-235. (2018). In parallel with systems theory, F.A. Hayek also opposed ideas of planning and saw the market as a "spontaneous order" and a "system of communication, "in which only "pattern prediction" is possible.

${ }^{58}$ This is a recurrent concern in Teubner's work. See, for example, his exchange with Antonio Negri in Gunther Teubner, Societal Constitutionalism and the Politics of the Common, 21 FINNISH Y.B. INT'L L. 2 (2010). For a critical engagement with this view, see Ioannis Kampourakis, CSR and Social Rights: Juxtaposing Societal Constitutionalism and Rights-Based Approaches Imposing Human Rights Obligations on Corporations, 9 GoETTINGEN J. INT'L L. 537, 566 (2019).

${ }^{59}$ On law's endogeneity in GVCs, see Dan Danielsen, How Corporations Govern: Taking Corporate Power Seriously in Transnational Regulation and Governance, 46 HARV. INT'L L.J.411 (2005).

${ }^{60}$ Teubner, supra note 58 , at 13 .

${ }^{61}$ One such example could be considered the emergence of the Accord on Fire and Building Safety in Bangladesh.

${ }^{62}$ Teubner, supra note 6, at 52. See also Neil Walker, Beyond the Holistic Constitution?, in The TwILIGHT OF Constitutionalism (Petra Dobner \& Martin Loughlin eds., 2012).

${ }^{63}$ Gunther Teubner, Self-Constitutionalizing TNCs? On the Linkage of "Private" and "Public" Corporate Codes of Conduct, 18 Ind. J. Global Legal STUd. 617 (2011).

${ }^{64}$ Jaakko Salminen, Contract-Boundary-Spanning Governance Mechanisms: Conceptualizing Fragmented and Globalized Production as Collectively Governed Entities, 23 IND. J. GLOBAL LEGAL STUD. 709, 713-14 (2016).
} 
responsibility of transnational corporations, ${ }^{65}$ the resulting corporate codes of conduct are considered an effective and binding form of private ordering. ${ }^{66}$

A second lens through which to understand the normative direction of constitutionalizing GVCs is that of human rights. Human rights make up an integral aspect of the decentered conceptualization of society that informs societal constitutionalism. However, in a clear shift from agents to structure, the crucial feature of human rights is not their role as guarantors of affected legal interests of individuals, but rather their function "as social and legal counter-institutions to the expansionist tendencies of social systems." ${ }^{67}$ The question behind the "horizontal effect" of human rights is not a question of balancing the rights of concrete actors-instead, it is an "ecological" question of the weight of the injury caused by the expansion of a social system to other functional systems. ${ }^{68}$ The case of labor and human rights violations in sweatshops is elucidating. In this case, it would be a mistake to consider factory managers as the only ones responsible, especially considering the price pressure imposed on them by lead firms. Yet, focusing only on lead firms is equally misleading. Often, arguments of lack of knowledge or control over suppliers' management of production have a basis as monitoring and auditing processes might be circumvented. It is, instead, "anonymous market forces" that are eventually responsible for the structural violence that characterizes sweatshops. ${ }^{69}$ Therefore, human rights need to be conceived as a defense against precisely such anonymous forces, rather than against specific actors.

Despite the normative direction of societal constitutionalism toward the democratization of the economy from within, there is no room for optimism for an overarching resolution to issues of justice and genuine fulfillment of human rights. The project of a utopian justice remains a conceptual impossibility. Humans are, by definition, neither the subjects nor the objects of communications - these are the social systems in which humans take part. As a result, society can never aspire to fully do justice to humans, who stand outside communication. At best, it can create the kind of irritations or "learning pressures" to social systems so that they remove unjust situations. But then, it can be asked, how do we know which situations are unjust? The way out for societal constitutionalism is to draw attention to spontaneous indignation, protest, and unrest. This is a move that reconnects a grand theory project with empirical reality and, in a way, it prepares the ground for the argument I will present on the possibilities for synthesis. While the claim that justice can only be construed in negative terms may be seen as anti-utopian, it shares the characteristic grand theory-like attribute of making broad claims about the nature of social order. The "negativity" of this overarching perspective captures the postmodern incredulity to narratives of incremental reform, a tendency present in the empirical analyses of GVCs discussed above. Drawing from the comparison between empirical socio-legal studies and societal constitutionalism I outlined in this section, I will now attempt to further elucidate the role of "grand theorizing" in the socio-legal field.

\footnotetext{
${ }^{65}$ E.g., the UN Guiding Principles on Business and Human Rights of 2011. For quasi-soft law legislative initiatives focusing on transparency, see also the EU Directive 2014/95 or the UK Modern Slavery Act of 2015.

${ }^{66}$ TeUBnER, supra note 6 , at 48 . Corporate codes are particularly promising as "civil constitutions" because they introduce not only primary rules for the protection of labor rights or the environment but also secondary rules that juridify reflexive processes that link the corporation with its environment. See Teubner, supra note 63, at 624. On the potential of corporate codes, see also, Anna Beckers, Enforcing Corporate Social Responsibility Codes: On Global Self-Regulation and National Private LaW (2015).

${ }^{67}$ Gunther Teubner, Transnational Fundamental Rights: Horizontal Effect?, 40 NETH. J.L. PHIL. 191, 210 (2011).

${ }^{68}$ Gunther Teubner, The Anonymous Matrix: Human Rights Violations by 'Private' Transnational Actors, 69 MOD. L. REV. 327, 330 (2006).

${ }^{69}$ Id. at 335.; Mark Anner et al., Toward Joint Liability in Global Supply Chains: Addressing the Root Causes of Labor Violations in International Subcontracting Networks, 35 CoMP. LAB. L. \& PoL'y J. 1, 3 (2013) (“[L]abor violations are not simply a factory-level problem that can be corrected by improved compliance monitoring; they are a pervasive and predictable outcome in an industry dominated by lead firms whose business model is predicated on outsourcing apparel production via highly flexible, volatile, and cost-sensitive subcontracting networks.").
} 


\section{How "Big" Should We Think in Law and Society?}

The discussion of the empirical research in GVCs indicated that the authors did not-with the exception of Anna Tsing - attempt to link their findings to an overarching theory of society or of the role of law and private regulation in conditions of globalization. Is there a value in extrapolating from empirical findings to more systematic theory-building? What is the place of social and legal theory-and especially of grand theory-in the socio-legal field and in connection to empirical scholarship?

Underlying empirical socio-legal work is the assumption, first, that objective social reality exists, and second, that it is, in some way, observable, intelligible, and even measurable. The existence of a material, social reality implies that phenomena occur within a specific socio-historical context. It is by gathering data within that context that researchers may find regularities and patterns behind social phenomena. By definition, then, all knowledge is partial and contextual. Any unitary account of the social order is at best reductive and at worst obfuscating, possibly manipulating data to advance transhistorical claims. ${ }^{70}$

On the one hand, relying on empirical data to address specific social problems has had a distinctly "progressive" and "reformist" character. Indeed, a cardinal aspect of legal realism was the urge to study the social facts behind legal endeavors, to demystify metaphysical legal doctrines through the knowledge of their social impact, and to shape a better, more moral law based on the teachings of sociology, economics, or anthropology. ${ }^{71}$ For example, in the U.S., this realist recruitment of empiricism and the sciences was the intellectual spearhead behind the New Deal policies in the $1930 \mathrm{~s}^{72}$ At the same time, however, the reliance on facts and data fueled the "rationalist" turn in social disciplines, namely the Popperian dictum that beliefs are rationally grounded only if they can pass an experimental test of falsifiability. ${ }^{73}$ This test was meant to distinguish between factual and normative claims, placing the social disciplines on the path to become "real" sciences. ${ }^{74}$ By separating the normative from the descriptive, while attributing scientific credence only to the latter, the rationalist stance was decisively anti-utopian. Thinking "big" in social philosophy was tantamount to "mystifying nonsense."

But can we so neatly distinguish between the factual and the normative? Or does the discernment of the factual already smuggle in normative preconceptions? According to Thomas Kuhn, our access to facts, in the light of which we are supposed to test our beliefs, is always filtered by existing "paradigms" of understanding. ${ }^{76}$ If our access to reality is dependent on contingent beliefs and paradigms of understanding, then the rationalist project begins to lose ground and the boundary between the factual and the normative becomes more porous. Knowledge is not partial and contextual; it is socially constructed. Postmodern constructivist positions that start from this premise would not normally dovetail with singular, overarching schemes of explanation. ${ }^{77}$ However, the constructivist position is in itself an overarching, singular explanatory scheme about society. Theoretical endeavors that start from such an epistemology cannot but morph into some form of grand theory. ${ }^{78}$ They are bound to prioritize concepts as opposed to

\footnotetext{
${ }^{70}$ C. Wright Mills, The Sociological imagination 22 (2000).

${ }^{71}$ Morton J. Horwitz, Transformation of American Law, 1870-1960: The Crisis of Legal OrthodoXy 189 (1992) (summarizing the reformist impetus of legal realism in which "detailed knowledge of social fact [provides] a necessary demystifying first step toward the goal of social reform").

${ }^{72}$ See Marcus J. Curtis, Realism Revisited: Reaffirming the Centrality of the New Deal in Realist Jurisprudence, 27 YALE J.L. \& HUMAN. 157 (2015).

${ }^{73}$ See POPPER, supra note 24.

${ }^{74}$ Quentin Skinner, The Return of Grand Theory in the Human Sciences 5 (Quentin Skinner ed., 2000).

${ }^{75}$ Popper, supra note 24, at 247 (citing Schopenhauer's critique to Hegel).

${ }^{76}$ See Thomas S. Kuhn, The Structure of Scientific Revolutions (2009).

${ }^{77}$ SKINNER, supra note 74 , at 12 .

${ }^{78}$ Id. at $12-13$ :
}

There is no denying that Foucault has articulated a general view about the nature of knowledge, that Wittgenstein presents us with an abstract account of meaning and understanding, that Feyerabend has a preferred and almost 
concrete social reality because they see concepts at the roots of all understanding. At the same time, the recognition that the factual cannot exist irrespective of some normative preconceptions implies that even an explicitly self-declared empirical approach, like that of Empirical Legal Studies, cannot help but convey - at least implicitly - a theory about the role of law in society and the way it mediates between power and reason. ${ }^{79}$ Even an instrumental approach to legal reform entails the commitment to a background prescriptive theory of the relevant area of social practice, as manifested at least in selecting the cases to be examined.

Fleshing out such normative commitments may lead to delimiting the role law can play in social transformation, acknowledging that it is only one among interrelated social frameworks where social hierarchies might be instantiated. ${ }^{80}$ For example, in that direction, societal constitutionalism delimits what law can achieve by daring a big claim about justice: That it is unattainable - at least through law. The determinism of this claim is only nuanced by its attachment to the contingency of the meaning of justice. ${ }^{81}$ For law to approach justice, it is neither enough to refer to its own internal principles (positivism) as justice searches for an extra-legal orientation, nor to appeal to metaphysical authorities beyond law that supposedly possess substantive criteria of justice (natural law). Instead, law is dependent on its "ecologies": Its social, human, and natural environment and the varying understandings of justice therein. ${ }^{82}$ Regardless of where one stands on this pluralist utopianism, it constitutes a type of normative thinking that goes beyond legal reform. Societal constitutionalism engulfs contingency, context, and local variation as parts of a singular explanatory and normative framework. Paradoxically, difference becomes the unifying theme of a constructivist, postmodern grand theory.

Is the dichotomy between empirical socio-legal approaches and constructivist grand theory approaches unbridgeable? Critical realism offers a way to imagine a possible middle ground or even a synthesis between empirical socio-legal studies and grand theory. Critical realism rejects the methodological individualism of explaining social phenomena via an ultimate recourse to the individual in a way that is reminiscent of systems theory: A study of society is not a study of the behavior of large groups but rather a study of the persistent relations between individuals or groups ${ }^{83}$ However, critical realism also acknowledges that society consists of real people and that "the material presence of social effects consists only in changes in people and changes brought about by people on other material things." ${ }^{4}$ While people unconsciously reproduce the structures that govern their lives, they retain agency in the process. The hegemony of particular social structures is ensured through the repetition of their performance. In turn, this repetition constitutes a particular social order and the individuals therein, defining the contours of their agency. ${ }^{85}$

Popperian method of judging scientific hypotheses, and even that Derrida presupposes the possibility of constructing interpretations when he tells us that our next task should be that of deconstructing them .... There is no paradox, in short, in giving pride of place to the iconoclasts: Almost in spite of themselves, they have proved to be among the grandest theorists of current practice throughout a wide range of the social disciplines.

\footnotetext{
${ }^{79}$ Hanoch Dagan et al., Legal Theory for Legal Empiricists, 43 L. \& Soc. INQUIRY 292 (2018).

${ }^{80}$ Nicola Lacey, Normative Reconstruction in Socio-Legal Theory, 5 Soc. \& LEGAL STUD. 131, 140, 146 (1996).

${ }^{81} \mathrm{It}$ is interesting to note that this determinist anti-individualism that leaves little room for human agency is common with that of structuralism. See, e.g., Louis Althusser, Louis Althusser Replies to John Lewis, 1 AusTL. LeFT ReV. 23, 29 (1972) (“[H] istory is a process without subject."). The contingent meaning of the discussed categories is the differentiating, poststructuralist factor. See Bernard E. Harcourt, An Answer to the Question: 'What is Poststructuralism?', (University of Chicago Public Law \& Legal Theory Working Paper No. 156, 2007).

${ }^{82}$ Gunther Teubner, Self-Subversive Justice: Contingency or Transcendence Formula of Law?, 72 MoD. L. REV. 1, 9 (2009).

${ }^{83}$ Bhaskar, supra note 9 , at 6 (explaining it would be impossible to give a non-social, for example, strictly individualistic explanation of an individual— "explanation ... always seems to involve irreducibly social practices").

${ }^{84} I$. at 8 . Materiality is different from "observability" but is rather defined through the function structures perform in the social world. For example, structures may not be observable but still perform a function such as the concept of a deity. See also Souza, supra note 23, at 24; Roy Bhaskar, A Realist Theory of SCIEnce (2008).

${ }^{85}$ Luis Eslava, The Teaching of (Another) International Law: Critical Realism and the Question of Agency and Structure, L. TEACHER 1, 4 (2019).
} 
Therefore, social structures, if only by reason of them constituting subjectivities, have a material, palpable manifestation in the real world. While this does not exclude that some aspects of the world are socially constructed, it allows a wide margin for empirical research to work with and elucidate this materiality.

Grand theories in sociological approaches to law base their normative output on presuppositions that are inevitably axiomatic. For example, societal constitutionalism's normative agenda of "democratizing the economy from within" follows from the presuppositions, first, that society is fragmented in different systems of communication and, second, that these systems cannot communicate directly. The impossibility of direct communication implies that top-down state intervention in the economy cannot be efficient, redirecting the focus of social transformation in system-internal processes. ${ }^{86}$ Yet, how do we know that these presuppositions are "true"?

Admitting that social structures possess materiality means that some type of empirical examination of them must be possible and that they are not accessible only through reason. Yet, at the same time, admitting the existence of structures that go beyond the individual use of private autonomy invites a level of abstraction capable of capturing processes that take place "beyond individual agency," such as the anonymous market forces defining sweatshops. Empirical socio-legal research has the capacity to uncover how social structures are shaped and negotiated in specific social practices, localities, and contexts. In Anna Tsing's words, "it is time to reimbue our understanding of the economy with the art of noticing." 87 A similar undertone echoes in Boaventura De Sousa Santos' argumentation for an "emancipatory common sense." 88 In that sense, empirical socio-legal studies can be most promising when they are not merely attuned to possible institutional reforms, but when they discover, inductively, elements of normative reconstruction of the particular area of social activity. What meaning do concepts like justice acquire in the human "ecologies" of the law? By turning the attention to "subaltern counterpublics" ${ }^{\prime 9}$ and giving them a voice, counter-hegemonic values that were so far unexplored may gain prominence, disrupting currently dominant ways of social ordering. In that direction, the fieldwork of De Sousa Santos on the parallel legality of the favelas in Rio de Janeiro provides a basis for theoretical insights on law, postmodernism, and social struggles. ${ }^{90}$ Similarly, Tsing's ethnographic research on supply chain capitalism shows how diversity is both the condition that makes value extraction from supply chains possible and a challenge to GVCs, that is, a possible opening to noncapitalist spaces. ${ }^{91}$ An inductive approach of descriptive and normative inquiry may never meet the requirements of the rationalist, "scientific" objectivity. Yet, it could be the underpinning of utopianism and normative legal thinking that imagines new institutional and social arrangements.

\section{E. Conclusions}

Both in Germany and the UK, sociological approaches to law have had internal divisions, methodological rifts, and divergent aspirations, while still sharing an external perspective to the study of law. While empirical socio-legal studies have strong institutional presence and influence in legal research and education in the UK, the same cannot be said about Germany. ${ }^{92}$ At the

\footnotetext{
${ }^{86}$ Gunther Teubner, After Legal Instrumentalism? Strategic Models of Post-Regulatory Law $310-12$ (Gunther Teubner ed., 1986) (considering direct, top-down regulation faces a "regulatory trilemma" of under-effectiveness, over-effectiveness, or regulatory capture).

${ }^{87}$ Anna Tsing, The Mushroom at the End of the World: On the possibility of Life in Capitalist Ruins 132 (2017).

${ }^{88}$ Boaventura de Sousa Santos, Towards a New Common Sense: Law, Science and Politics in the Paradigmatic Transition 46-50 (1995).

${ }^{89}$ See Nancy Fraser, Rethinking the Public Sphere: A Contribution to the Critique of Actually Existing Democracy, Soc. TEXT 56 (1990).

${ }^{90}$ De Sousa Santos, supra note 88. See also Peter FitzPatrick, Law and State in Papua New Guinea (1980).

${ }^{91}$ Tsing, supra note 53 , at 171-72.
} 
same time, Luhmann, Teubner, and others in sociological jurisprudence from a systems-theory perspective have had a lasting influence in German legal academia. ${ }^{93}$ In this Article, I have tried to show that these projects do not differ only in their methodologies or their style but also in their epistemologies and ontological perspectives on social reality. Where empirical socio-legal studies tend to see an objectively existing social reality that can be probed and studied through the collection of data, societal constitutionalism - and legal autopoiesis more broadly - see a constructed and fragmented reality in which there is no "unifying mode of cognition." "Th This structures different ways to approach societal problems and different ambitions in suggesting explanatory and normative frameworks. Indicatively, the tendency of societal constitutionalism to decipher social reality through structures, such as the communications of social systems, rather than through human agency, leads to holistic explanatory and normative frameworks despite taking into consideration context and difference. On the contrary, the focus of empirical socio-legal studies on observable social reality and concrete individuals renders such approaches self-aware of the partiality of their contribution.

The discussion of transnational private regulation revealed these rifts. Empirical socio-legal studies tend to focus on the dynamics between agents in GVCs and on the concrete impact of transnational private regulation, often attempting to uncover what could make this form of legal pluralism more effective in protecting labor rights or the environment. Societal constitutionalism emphasizes the need for structures and mechanisms that may generate self-regulatory dynamics within social systems, such as, for example, human rights or the corporate codes of lead firms. While the content of these mechanisms may be context-specific, the idea of self-limitation-as opposed to, for example, external limitation-is a necessary and unavoidable result of the theoretical premises of societal constitutionalism.

The quest to imagine possible synergies between the discussed ways of thinking about the law sociologically extends beyond the ambitions of this Article. Indeed, the quest to adequately capture the materiality and meaning of "context" is ever-present in socio-legal studies. ${ }^{95}$ Synthesis of the empirical and the grand theory perspective is premised on the idea that social structures, such as the "anonymous market forces", do, in fact, have material existence, at least because they shape and condition individuals. Yet, while the "individual" is conditioned through its contact with social structures, empirical research targets subjectivities under continuous forces of transformation. Even if a certain outline of social structures is postulated, such as the asymmetry of power relations in value chains, the outcome of the produced subjectivities remains uncertain. For instance, workers could endorse corporate codes and aspire to be part of a broader corporate culture, they could reject them as paternalizing, or they could only use them strategically. Starting inductively from the materiality of social structures and the conditioned subjectivities to eventually uncover and normatively evaluate processes beyond individual agency may be a key in thinking "big" in law and society.

\footnotetext{
${ }^{92}$ Bora, supra note 2 , at 640 .

${ }^{93}$ That does not mean that in each examined country the different approach is absent. For example, systems theory has influenced scholars working in the UK, like Emilios Christodoulidis, Jen Hendry, Andreas Philippopoulos-Mihalopoulos, Christopher Thornhill and others. Similarly, empirical socio-legal research is of course also present in Germany, often under the title "interdisciplinary legal research" ("Interdisziplindre Rechtsforschung"). See SusAnNE BAER, RECHTSSOZIOLOGIE: EINE EINFÜHRUNG IN DIE INTERDISZIPLINÄRE RECHTSFORSCHUNG (3d ed. 2017).

${ }^{94}$ Teubner, supra note 19 , at 738.

${ }^{95}$ Peer Zumbansen, Transnational Law as Socio-Legal Theory: The Challenges for "Law in Context" in a Divided World, 67 BuFf. L. REV. 909, 911 (2019).
}

Cite this article: Kampourakis I (2020). Empiricism, Constructivism, and Grand Theory in Sociological Approaches to Law: The Case of Transnational Private Regulation. German Law Journal 21, 1411-1426. https://doi.org/10.1017/glj.2020.82 